\title{
TOO EARLY, TOO LATE: THE RELEVANCE OF ZBYNĚK Z. STRÁNSKÝ FOR GERMAN MUSEOLOGY

\section{MARKUS WALZ}

\section{ABSTRACT/ABSTRAKT:}

Zbyněk Stránský's influence on German museology has three facets: in the GDR, he contributes publications and lectures to an intense process of defining museology as an academic discipline, starting in the late 1970ies. Controversies concern his concept of museality - with the accusation of a non-Marxist and therefore non-scientific position. Western Germany starts a discussion about the discipline in 1988. After the German unification, the interest in museology as an academic field nearly vanished although Stránský publishes several German texts with new intellectual accents in the periodical Museum aktuell. Friedrich Waidacher's free variations of Stránský's theoretical models receive much more reception. Therefore it doesn' $t$ surprise that most of the teaching staff of museum related study programmes in Germany declare little knowledge or interest concerning Stránský and his thoughts. A search of Stránský's neologism museality by library catalogues, Google and Google Scholar (in German) presents a similar result: a "correct" use of the term by the museological inner circle, rare cases of indifferent use, and some new trials to create this term with another meaning.

Příliš brzy, př́liliš pozdě: význam Zbyňka Z. Stránského pro německou muzeologii

Vliv Zbyňka Stránského na německou muzeologii má tři aspekty: v NDR přispěl svými publikacemi a přednáškami $\mathrm{k}$ intenzivnímu procesu formování muzeologie jako vědního oboru, který započal koncem 70. let 20. století. Jeho koncept muzeality však narazil na odpor bylo mu vyčítáno, že není marxistický a tudíž není vědecký. V západním Německu se začalo o muzeologii jako vědě diskutovat $v$ roce 1988. Po sjednocení Německa zájem o muzeologii jako akademickou disciplínu značně ochabl, ačkoli Stránský publikoval v periodiku Museum aktuell několik textů v německém jazyce, které obsahují nové intelektuální podněty. Mnohem více pozornosti vzbudil Friedrich Waidacher se svými volnými variacemi na Stránského teoretické modely. Proto není nijak překvapivé, že většina pedagogů, kteří v Německu působí v studijních programech zaměřených na muzeologii, ví o Stránském jen málo a nejeví o jeho myšlenky dostatečný zájem. Př̀i hledání Stránského neologizmu muzealita v katalozích knihoven, či na serverech Google a Google Scholar (v němčině) narazíme na podobný výsledek: „správné“ používání termínu v muzeologických odborných kruzích, vzácné př́ipady indiferentního použití a několik nových pokusů o použití tohoto pojmu v odlišném významu.

\section{KEYWORDS/KLÍČOVÁ SLOVA:}

museology - GDR - Germany - museality - cultural memory muzeologie - NDR - Německo muzealita - kulturní pamět

\section{Stránský and the "museological season" in the GDR}

The late 1970ies and the 1980ies are a period of vivid interest in museological theory in the GDR: a new scientific periodical, Museologische Forschung, starts in 1982, the Berlin University accepts the Introduction to Museology ${ }^{1}$ by Klaus Schreiner, director of the museum of agricultural history at Alt-Schwerin, as dissertation. The GDR's most important natural history museum a part of the Berlin University establishes Ilse Jahn as docent of natural history museology in 1980. Museological thoughts out of other states in the Eastern bloc are of high interest. In 1981, the "Institut für Museumswesen" pragmatically offers a typewritten translation of Stránský's Úvod do studia muzeologie (1979). Stránský contributes two texts in German to the journal Neue Museumskunde, dealing with the educational relevance of museum exhibitions ${ }^{2}$ and the development of museological terminology. ${ }^{3}$

This "museological season" is based on a bottom-up campaign for museology as a new research field and study programme; this will not be

\footnotetext{
1 SCHREINER, Klaus. Einführung in die Museologie - ein Beitrag zu den theoretischen Grundlagen der Museumsarbeit. Neubrandenburg, 1982 [published as typoscript].

2 STRÁNSKÝ, Zbyněk Z. Die Bildungs- und Erziehungsziele der Museumsausstellung als pädagogisch-museologisches Anliegen. Neue Museumskunde, 1982, vol. 25, pp. 45-51. 3 STRÁNSKÝ, Zbyněk Z. Museologische Terminologie. Neue Museumskunde, 1988, vol. 31, pp. 12-17.
} 
successful in a centralistic dictatorship without a solid (and ideologically proofed) scientific reason. Therefore, the GDR - contrasting to the Federal Republic - knows discussions about the research interest, methodology, terminology, and structure of the discipline.

Several phenomena are proposed as the object of museological research interest - quite similar to the international discourse. Schreiner refuses Stránský's museality (as a special documentary value of the asset) like any additional value to the scientific evidence of the object. He criticizes museality (as a human relationship to the environment) because of its "questionable closeness to bourgeois values" by using anthropological arguments and neglecting the Marxist dialectic materialism. ${ }^{4}$ Five years later, he writes a serious parody on Stránský: the specific documentary value of assets can't be the object of museological research interest - parallel to Stránský's reflections - because these values were not existing within the material but only by evaluation; using the Marxist point of view, these evaluations - Stránský's younger definition of museality - can' $t$ be permanent but have to change with the linear development of society. For Schreiner, the contrary position disguises bourgeois-imperialistic class interests ${ }^{5}$ - a precise shot against Stránský's opinion that the cultural values of museality are transtemporary and transpersonal ${ }^{6}$ although Stránský accepts that the criteria and hierarchies of values are temporary and therefore changeable phenomena. ${ }^{7}$

\footnotetext{
4 SCHREINER, Einführung in die Museologie (see reference 1), vol. 2, pp. 11-12.

5 SCHREINER, Klaus. Forschungsgegenstand der Museologie und Disziplingenese. Neue Museumskunde, 1987, vol. 30, p. 7.

6 STRÁNSKÝ, Zbyněk Z. Museumsgegenstand eine Welt sui generis. Metaphysik des

Museumsgegenstandes. Neues Museum. Die österreichische Museumszeitschrift, 1993, iss. 3/4, p. 55 .

7 STRÁNSKÝ, Zbyněk Z. Metamuseologie. Museum aktuell, 2003, iss. 92, p. 3977.
}

Schreiner notes that Stránský's ideas have 'infected' many museologists in the GDR, but mentions as well that he didn' $t$ get the approval of the "Institut für Museumswesen" for publishing ideological comments against Stránský. ${ }^{8}$ Schreiner's definition of museality as the "suitability of an asset for the museum collection" ${ }^{\prime \prime}$ avoids any relation to Stránský. Stránský himself remembers an antagonism of "Stránskýsts" and "Anti-Stránskýsts" in the GDR culminating in Schreiner's letter campaign "plus and minus of some of Stránský's museological opinions" criticizing a non-Marxist and therefore non-scientific position. Stránský himself interpreted this critic as a comment on his - within publications never declared - intellectual connection to the West German philosophers Martin Heidegger and Karl Popper. ${ }^{10}$

Like final point, a handbook of the museology of history is published in 1988, a cooperation of the Soviet Union and the GDR. This book defines: "Museology is a social science which researches the processes and laws of the conservation of social information and of the communication of knowledge and emotions by museum assets." ${ }^{11}$ And, closer to Stránský: "Museology researches that specific relation of the human being and her/his environment which causes that museum meaning and a museum value is attributed to certain assets." ${ }^{2}$

8 HANSLOK, Andreas. Museologie und Archivwissenschaft in der DDR. Abgrenzung und Annäherung zweier Nachbarwissenschaften. Marburg: Tectum, 2008, p. 113.

9 SCHREINER, Klaus. Museologische TerminiAuswahl. Neubrandenburg, 1982 [published as typoscript], p. 51.

10 STRÁNSKÝ, Zbyněk Z. Ist Museologie eine kommunistische Wissenschaft? Eine Entgegnung auf deutsche Einstellungen. Museum aktuell, 2001, iss. 68, p. 2759.

11 RAZGON, Avram M. Museologie als

wissenschaftliche Disziplin. In HERBST, Wolfgang and Konstantin G. LEVYKIN (eds.). Museologie. Theoretische Grundlagen und Methodik der Arbeit in Geschichtsmuseen. Berlin (East): Deutscher Verlag der Wissenschaften, 1988, p. 19 [translation M. W.].

12 Ibidem, p. 27 [translation M. W.].
The discourse concerning the internal structure of museology ventilated some terms which are well known from the international level - and of course from the Brno ISSOM - like theoretical and applied museology or the history of museums and museology. The curriculum of the first realized study programme, natural history museology, showed a solitary solution with the division in general museology (the museology of natural history museums!) and special museologies, from anthropology to zoology. ${ }^{13}$

\section{From the "old" Federal Republic to Unified Germany}

A Bavarian discussion about museological study programmes starts in 1978. Ten years later, this - still unsuccessful - idea motivates the topic "museology - new ways, new aims" for a joint conference of ICOM Austria, ICOM Germany (Federal Republic), and ICOM Switzerland. The Bavarian reflections are presented, and Stránský gives a lecture on museology as a separate discipline. ${ }^{14}$

After the German unification, the former GDR college for museologists is transformed to a study programme of the Leipzig University of Applied Sciences. This institution starts a series of museological conferences. Stránský speaks on museology as a separate discipline again. Retrospectively, it can be recognized that Stránský gets his only German intellectual echo - except of the ideological controversy with Schreiner - at Leipzig: the professor of museum pedagogic at this uni-

\footnotetext{
13 JAHN, Ilse. Zum Gegenstand der Museologie und seine Umsetzung in Erfahrungen mit Lehrprogrammen „Museologie“ im Museum für Naturkunde Berlin. Museologische Forschung. Beiträge und Informationen, 1982, iss. 2, pp. 32, 36.

14 STRÁNSKÝ, Zbyněk Z. Die theoretischen Grundlagen der Museologie als Wissenschaft. In AUER, Hermann (ed). Museologie. Neue Wege - Neue Ziele. Bericht über ein internationales Symposium, veranstaltet von den ICOM- Nationalkomitees der Bundesrepublik Deutschland, Österreichs und der Schweiz 11.-14. Mai 1988 am Bodensee. München: K.G. Sauer, 1989, pp. 38-47.
} 
versity discusses the relation of museum education and museology; he recurs to Stránský's graphic model of the intersections of museology and other disciplines and depicts an analogous multi-dimensional model. ${ }^{15}$

In the beginning millennium, Stránský tries to open new museological horizons by publishing some essays in German. He touches evidences of the sub-atomic physic and Pierre Noras's concept of "lieux de mémoire" ${ }^{16}$ Indirectly, he mentions contact points between museality and the influential theory of the cultural memory, introduced since 1992 by the German scientists Jan and Aleida Assmann - with his obvious preference compared to any discourse on cultural heritage. ${ }^{17}$ The German museological discourse runs just the opposite way without any reaction to Stránský.

The Austrian Friedrich Waidacher, 1977-94 director of the Landesmuseum Joanneum at Graz, has the greatest importance for the dissemination of Stránský's ideas in German language by writing a voluminous Handbook of General Museology (1993). This publication got a second, revised, and a third edition $(1996,1999)$ and four translations (1999 Slovakian, 2005 Chinese and Ukrainian, 2007 Lithuanian) - certainly the best known museological publication in German language.

The relation between Stránský's ideas and Waidacher's handbook seems quite fragile, although Waidacher indicates that the structure of his

15 VOGT, Arnold. Museologie und

Museumspädagogik. Ihre Rahmenbedingungen und Perspektiven in Wissenschaft und Praxis. In FLÜGEL, Katharina and Arnold VOGT (eds.) Museologie als Wissenschaft und Beruf in der modernen Welt. Weimar: Verlag und Datenbank für Geisteswissenschaften, 1995, pp. 60-61, 65.

16 STRÁNSKÝ, Zbyněk Z. Cyberraum und Museumskultur. Museum aktuell, 2007, iss. 133, pp. 20-24.

17 STRÁNSKÝ, Zbyněk Z. Metamuseologie. Museum aktuell, 2003, iss. 92, pp. 3975-3976. book basically follows Stránský. ${ }^{18}$ It is typical for Waidacher's writing strategy to quote precisely that Stránský created the term museality, but to continue with his own definition; any discussion or genealogy of this definition is missing. ${ }^{19}$ Clearly, Stránský's anonymous critic concerning academic authors who avoid correct references to originators $^{20}$ aims to Waidacher.

Waidacher's museology has four sub-disciplines: meta-museology, historical, theoretical, and applied museology. Special museologies as well an aspect in Stránský's thoughts - are refused with a single sentence. ${ }^{21}$ Consequently, the book irritates with its title "general museology" but no mentioned contrary. Stránský criticises on the one hand that the model is not new but nearly identical with the structure of his own Brno study programme since the 1980ies; on the other hand, he refuses the integration of epistemological aspects in the system of the science itself (meta-museology). ${ }^{22}$ Ten years after Waidacher's handbook, Stránský presented his revised structure of museology in German language: now with four sections because of the additional "abstract" or "structural museology" as a synchronous analytical equivalent to the diachronous historical museology ("genetic museology"). ${ }^{23}$

Realizations of both imaginations are missing in Germany till today except of some parallels within study programmes of applied museology. A discussion about disciplinary structures does also

\footnotetext{
18 WAIDACHER, Friedrich. Handbuch der Allgemeinen Museologie. 2nd, revised edition. Wien: Böhlau, 1996, p. 140.

19 Ibidem, pp. 33-34

20 STRÁNSKÝ, Zbyněk Z. Noch eine „knapp gefaßte Museologie“. Museum aktuell, 2006, iss. 131 , p. 6

21 Ibidem, p. 44

22 STRÁNSKÝ, Zbyněk Z. Metamuseologie.

Museum aktuell, 2003, iss. 93, p. 4028.

23 Ibidem, pp. 4029, 4153.
}

not happen. Symptomatically, an introduction to museology explains that Stránský developed the three sub-disciplines, it mentions the term "genetic" instead of "historical" but nothing about the "abstract museology"; the illustration follows Waidacher while the text does not at all explain his fourth sub-discipline, meta-museology. ${ }^{24}$

\section{The reception of Stránský's ideas in Germany today}

For gaining an impression of Stránský's recent academic relevance in Germany, I held an e-mail survey in April/May of 2016 addressed to the teaching staff of university study programmes. Although museums might be a topic of a wide range of disciplines - from art history to zoology - a narrow sample was preferred in order to avoid either a majority of missing answers or a lot of not interpretable negative answers. Therefore, the survey was limited to the nine German programmes concerning museum work or cultural heritage: "Art and Culture Mediation" (Bremen), "Historical and Cultural Anthropology" (Tübingen), "Jewish Museology" (Heidelberg), "Museography" (Berlin), "Museology" (Leipzig), "Museology" (Würzburg), "Museum and Exhibition" (Oldenburg), "European Cultural Heritage" (Frankfurt/Oder), and "Cultural Heritage" (Paderborn). "Art History and Museology" (Heidelberg) was excluded because the museological part is completely imported by the École du Louvre, Paris; Tübingen was included in view of the denomination "cultural anthropology, museum science" of one professorship.

My simple e-mail questionnaire was reduced to three open questions: first the relevance of Stránskýs ideas and theories for the recent individual academic work, second refer-

24 FLÜGEL, Katharina. Einführung in die Museologie. Darmstadt: Wissenschaftliche Buchgesellschaft, 2005, pp. 17-18. 
ences to Stránský's ideas within the individual lectures, and third the preferred authors if other thoughts are estimated as more inspiring. The invitation to free-text answers seemed to be sufficient for gaining a first impression and as well individual verbalizations. This very basic way instead of standardized answering proposals was chosen by supposing that an elaborated online questionnaire might deter more from answering than three, directly visible questions.

I got 19 replies to 36 sent e-mails (53\%), two oral answers included. Eight of the nine universities are represented; eight answers (42 \%) have their origin in the same institution. Most of the replies don't follow the three questions and answer in a shorter way.

The answers can be categorized into four positions. The majority (10 of 19) signalizes little knowledge or interest. One answer was given orally in another situation: During an academic round table discussion, a Dutch colleague asked for the museological position of this institute and - I think - he got the answer to my questions ("we do not at all deal with topics like Stránský"). The second group (4 of 19) signalizes knowledge ("I know Stránský's relevance for the scientific museology") but as well Stránský's irrelevance for their individual research and lectures ("I refer to other thoughts and don' $t$ remark any fruitful use of Stránský's ideas for my subject"). One person answers that individual relevance is missing but that another colleague - who didn' t answer - refers to Stránský as part of the history of the discipline. The third group (4 of 19) gives some details. Two persons historize Stránský ("mentioned as one of the founders of museology"), two persons report an indirect reference ("more often, we use Waidacher who follows Stránský intensely"). A single answer touches the topic closely by stressing the relevance of fundamental definitions, interdisciplinary sight, and philosophical foundation; further on, individual effects are mentioned "'Stránský inspires me with his theories of the authenticity of musealia and with his idea of the irreplaceable musealia").

Only three answers touch the question concerning alternative literature. All of them name Waidacher; other mentioned authors are Gottfried Korff, Krzysztof Pomian, and Anke te Heesen. One person additionally sent the actual literature list of the introductory module. Explanations of these preferences or comparisons to Stránský's work are missing.

\section{The actual use of the term mu- seality in German language}

A second impression of Stránský's contemporary relevance can be received by a search of his neologism museality (in its German expression "Musealität") with the meta-catalogue of German libraries (including the German National Library), Google, and Google Scholar. The results belong to three categories: a museological or an indifferent use of the term, and new trials to create this term.

The museologically informed use of the term is limited to authors who are part of the museological discourse like the Swiss Schärer or the Austrian Waidacher, expanded by one academic librarian. All of them certainly know some of Stránský's texts. A broader appearance of the term in its museological meaning is missing.

The indifferent position is clearly shown by some texts with the title word "Musealität" but without any explanation in the body text - for example, the art historian and museum director Kraus gives "Musealität" an unclear meaning between the use as museum exhibit and the status of a musealium; ${ }^{25}$ for Jeggle, professor for European Ethnology, museality means professional museum work. ${ }^{26}$ Some examination theses (concerning different topics) integrate one or another museological publication into their footnotes but don' t correctly connect these texts with their understanding of museality: Weber quotes Waidacher and Flügel and uses one time the term - without definition - to announce her chapter about the historical development of a museum type; ${ }^{27}$ Kühl quotes a definition of museology by Waidacher and continues that it is easy to identify museality in exhibitions because the exhibition context helps the visitors to reconstruct a past relation of man to reality; ${ }^{28}$ Huber explains museality as the presentation of authentic assets within a museum exhibition. ${ }^{29}$ In September 2016, the "Klassik Foundation Weimar" organizes a conference dealing with collections and exhibitions concerning the literary subject Faust; the title is "Faust collections: genealogies, media, museality".

Some people without any contact to museology feel themselves free to create the neologism again. Nell (the only German language monograph with the title word "Musealität") defines that the process of musealization leads to the state mu-

\footnotetext{
25 KRAUS, Stefan. Künstlerbücher: Über die Musealität eines zeitgenössischen Mediums. Das Münster. Zeitschrift für christliche Kunst und Kunstwissenschaft, 2011, vol. 64, pp. 354-365.

26 JEGGLE, Utz. Subjektive Heimat - objektive Musealität. Zum Verhältnis von subjektiver Erlebnisfähigkeit und objektiven Ereignissen. In EBELING, Susanne (ed.). Literarische Ausstellungen von 1949 bis 1985. Diskussion, Dokumentation, Bibliographie. München: Walter De Gruyter, 1991, pp. 77-93.

27 WEBER, Lena. Klostermuseen im deutschsprachigen Raum. Bonn, University, 2013, p. 20. Dissertation.

28 KÜHL, Alicia. Modenschauen. Die Behauptung des Neuen in der Mode. Bielefeld: Transcript, 2015, p. 77.

29 HUBER, Leonhard. Wunderkammer Cyberspace? Gestaltung und Rolle digitaler Museumsinformationssysteme. Eisenstadt, Fachhochschule, 2002, p. 1. Diplomarbeit.
} 
seality. ${ }^{30}$ The working group "aesthetic of religion" of the German association of comparative religion studies (DVRW) organizes its third conference May 2009 in Munich: "the development of basic terms of the aesthetic of religion by the example museality". The published lectures ${ }^{31}$ show an understanding of the term similar to Nell (without a reference).

Obviously, museality is neither a very common nor a clearly defined German term. One reason for this situation can be found in the genesis of the term and the actual museological discourse. Stránský introduces museality while reflecting the documentary value of authentic assets. All of Stránský's German texts concerning museality were published in the 1980ies or later and present the younger definition as a specific relation of man to reality expressed by selecting and conserving objects which represent certain cultural values. It might be a problem of translations that the musealia are sometimes representations or representatives, ${ }^{32}$ sometimes the carrier of museality. ${ }^{33}$ What an object is carrying belongs to it and no more to the selecting person - the older definition of museality seems to be mixed into the younger one. A similar misunderstanding can be found in the phrase that museology identifies things as "representants of the memory value,

30 NELLE, Anja. Musealität im städtischen Kontext. Untersuchung von Musealitätszuständen und Musealisierungsprozessen am Beispiel dreier spanisch-kolonialer Welterbeortschaften. Cottbus, Technical University, 2007, p. 11. Dissertation.

31 Journal of Religion in Europe, 2011, vol. 4, iss. 1 .

32 STRÁNSKÝ, Zbyněk Z. Museumsgegenstand eine Welt sui generis. Metaphysik des Museumsgegenstandes. Neues Museum. Die österreichische Museumszeitschrift, 1993, iss. 3/4, p. 54

33 STRÁNSKÝ, Zbyněk Z. Hat die Museologie einen Sinn? In SCHIMPFF, Volker and Wieland FÜHR (eds.). Historia in Museo. Festschrift für Frank-Dietrich Jacob zum 60. Geburtstag. Langenweißbach: Beier \& Beran, 2004, p. 475. of museality" 34 or that the musealia as carriers of museality "acquire the cultural value of memory". ${ }^{35}$

This shift of meaning is less noticed. Even the newest museological encyclopedia recurs to Stránský but defines museality only with the cultural value of musealia. ${ }^{36}$ Some German-language authors follow this way like the Swiss Roger Fayet ${ }^{37}$ or use museality without definition in the phrase "objects as carrier of museality" 38 like the Austrian Marlies Raffler.

The best known definition of museality in German language is written by Waidacher and follows Stránský's younger position: "a specific recognizing and valuating relationship of the human being to reality. [...] It means that the human being estimates selected objects as evidences of certain phenomena in that way that he/she wants to conserve them without limitation and to communicate them to society." ${ }^{39}$ The glossary of Waidacher's last book presents a similar definition but the body text speaks of musealia which can "carry" or "express" museality; as well it is mentioned that an object gains museality by detailed research and documentation. ${ }^{40}$

\footnotetext{
34 STRÁNSKÝ, Zbyněk Z. Museumsgegenstand eine Welt sui generis. Metaphysik des Museumsgegenstandes. Neues Museum. Die österreichische Museumszeitschrift, 1993, iss. 3/4, pp. 53-54.

35 STRÁNSKÝ, Zbyněk Z. Metamuseologie. Museum aktuell, 2003, iss. 92, p. 3977.
}

36 DESVALLÉES, André and François MAIRESSE (eds.). Dictionnaire encyclopédique de muséologie. Paris: Armand Colin, 2011, p. 625.

37 FAYET, Roger. Das Vokabular der Dinge. Österreichische Zeitschrift für Geschichtswissenschaften, 2007, vol. 18, p. 7. 38 RAFFLER, Marlies. Museum - Spiegel der Nation? Zugänge zur Historischen Museologie am Beispiel der Genese von Landes- und Nationalmuseen in der Habsburgermonarchie. Wien: Böhlau, 2007, p. 63.

39 WAIDACHER, Friedrich. Handbuch der Allgemeinen Museologie. 2nd, revised edition. Wien: Böhlau, 1996, p. 34 [translation: M. W.].

40 WAIDACHER, Friedrich. Museologie - knapp gefasst. Wien/Köln/Weimar: Böhlau, 2005, pp. 28, 59, 320 .
In the same way, the Swiss Martin Schärer first quotes Waidacher's definition of museality, but further on, he writes about the "museality of things", museality as a quality of musealia by referring to a specific relation between man and reality, and about pieces of modern art which have got museality just at their origin. ${ }^{41}$ In another argumentation (without references), he uses museality as the term for a quality which is won by an asset on the occasion of its musealization. ${ }^{42}$ The academic librarian Thomas Fuchs first quotes Waidacher's anthropological constant museality, but in the following sentence, he writes about museality in the meaning of a specific quality of musealia as a vehicle of remembrance. ${ }^{43}$

\section{Conclusion}

Within 40 years, Stránský contributed to museological theory and epistemology. He repeated his central points and developed them by repeating. On the other hand, he had an open mind for new ideas und published those as well. He crossed the border of understanding the Czech language by publishing as well in German. But the remarkable fruits are quite poor even as his arguments are welcome like in the GDR.

Stránský originated several aspects and terms, but a broader reception in German language begins with Waidacher's handbook - in Stránský's eyes, an illegitimate daughter version. Stránský's later proposals

41 SCHÄRER, Martin R. Die Ausstellung. Theorie und Exempel. München: Müller-Straten, 2003, pp. $47,51,61,64$.

42 SCHÄRER, Martin R. Hat das Kunstwerk einen besonderen Status? Oder: Sind alle Objekte museologisch gleich? [online]. [cit. 2016-08-25] Available from www: <http://edoc.hu-berlin. de/kunsttexte/2009-3/schaerer-martin-r.7/PDF/ schaerer.pdf $>$.

43 FUCHS, Thomas. Bibliotheken zwischen kultureller Memoria, Wissenschaft und Musealität. In FUCHS, Thomas (ed.). Das Buch in Antike, Mittelalter und Neuzeit. Sonderbestände der Universitätsbibliothek Leipzig. Wiesbaden: Otto Harrassowitz Verlag, 2012, p. 5. 
were published without an echo: German museum professionals seem to be content with a voluminous but ageing handbook.

Stránský hoped for intellectual collaboration but got quotations of different quality. He criticized the introductions of Flügel and Waidacher for writing individual opinions instead of searching evidence. He noted that these university docents didn't show enough professional museological penetration of the topic - for instance in Flügel's manner to present a voluminous bibliography which predominantly consists of authors who share her own opinion. ${ }^{44}$

Looking back, Stránský declares to be satisfied that the functionality of his neologism museality is proofed by its use ${ }^{45}$ - in what manner ever. Regarding the developments on this low level, Stránský could repeat his critical note of 1988 in 2016 without actualizing it: "We can' $t$ carry on contenting ourselves with a simply intuitive understanding of some terms, using them without connection to the terminological system [...]. Some theoretical publications show ignorance about existing literature, the domestic as well as the foreign one. Further on, authors often aren' $t$ capable of arguing on the necessary theoretical level. On this way, we'll hardly acquire objective terms [...]."46

\section{BIBLIOGRAPHY:}

DESVALLÉES, André and François MAIRESSE (eds.). Dictionnaire encyclopédique de muséologie. Paris: Armand Colin, 2011. ISBN 978-2-200-27037-7.

44 STRÁNSKÝ, Zbyněk Z. Noch eine „knapp gefaßte Museologie“. Museum aktuell, 2006, iss. 131 , p. 6 .

45 STRÁNSKÝ, Zbyněk Z. Museumsgegenstand eine Welt sui generis. Metaphysik des

Museumsgegenstandes. Neues Museum. Die österreichische Museumszeitschrift, 1993, iss. 3/4, p. 53.

46 STRÁNSKÝ, Zbyněk Z. Museologische Terminologie. Neue Museumskunde, 1988, vol. 31, p. 15 [translation: M. W.].
FAYET, Roger. Das Vokabular der Dinge. Österreichische Zeitschrift für Geschichtswissenschaften, 2007, vol. 18, pp. 7-31.

FLÜGEL, Katharina. Einführung in die $M u-$ seologie. Darmstadt: Wissenschaftliche Buchgesellschaft, 2005. ISBN 978-3-534-09232-1.

FUCHS, Thomas. Bibliotheken zwischen kultureller Memoria, Wissenschaft und Musealität. In FUCHS, Thomas (ed.). Das Buch in Antike, Mittelalter und Neuzeit. Sonderbestände der Universitätsbibliothek Leipzig. Wiesbaden: Otto Harrassowitz Verlag, 2012, pp. 1-35. ISBN 978-3-447-06689-1.

HANSLOK, Andreas. Museologie und Archivwissenschaft in der DDR. Abgrenzung und Annäherung zweier Nachbarwissenschaften. Marburg: Tectum, 2008. ISBN 978-3-8288-9581-2.

HUBER, Leonhard. Wunderkammer Cyberspace? Gestaltung und Rolle digitaler Museumsinformationssysteme. Eisenstadt, Fachhochschule, 2002. Diplomarbeit.

JAHN, Ilse. Zum Gegenstand der Museologie und seine Umsetzung in Erfahrungen mit Lehrprogrammen „Museologie“ im Museum für Naturkunde Berlin. Museologische Forschung. Beiträge und Informationen, 1982, iss. 2, pp. 21-36.

JEGGLE, Utz. Subjektive Heimat - objektive Musealität. Zum Verhältnis von subjektiver Erlebnisfähigkeit und objektiven Ereignissen. In EBELING, Susanne (ed.). Literarische Ausstellungen von 1949 bis 1985. Diskussion, Dokumentation, Bibliographie. München: Walter De Gruyter, 1991, pp. 77-93. ISBN 978-3-11$-153950-8$.

Journal of Religion in Europe, 2011, vol. 4, iss. 1.

KRAUS, Stefan. Künstlerbücher: Über die Musealität eines zeitgenössischen Mediums. Das Münster. Zeitschrift für christliche Kunst und Kunstwissenschaft, 2011, vol. 64, pp. 354-365.

KÜHL, Alicia. Modenschauen. Die Behauptung des Neuen in der Mode. Bielefeld: Transcript, 2015. ISBN 978-3-8376-2885-2.

NELLE, Anja. Musealität im städtischen Kontext. Untersuchung von Musealitätszuständen und Musealisierungsprozessen am Beispiel dreier spanisch-kolonialer Welterbeortschaften. Cottbus, Technical University, 2007. Dissertation.
RAFFLER, Marlies. Museum - Spiegel der Nation? Zugänge zur Historischen Museologie am Beispiel der Genese von Landes- und Nationalmuseen in der Habsburgermonarchie. Wien: Böhlau, 2007. ISBN 978-3-205-77731-1.

RAZGON, Avram M. Museologie als wissenschaftliche Disziplin. In HERBST, Wolfgang and Konstantin G. LEVYKIN (eds.). Museologie. Theoretische Grundlagen und Methodik der Arbeit in Geschichtsmuseen. Berlin (East): Deutscher Verlag der Wissenschaften, 1988, pp. 16-43. ISBN 978-3-326-00229-3.

SCHÄRER, Martin R. Die Ausstellung. Theorie und Exempel. München: MüllerStraten, 2003. ISBN 978-3-932704-75-8. SCHÄRER, Martin R. Hat das Kunstwerk einen besonderen Status? Oder: Sind alle Objekte museologisch gleich? [online]. [cit. 2016-08-25] Available from www: <http://edoc.hu-berlin.de/kunsttexte/2009-3/schaerer-martin-r.7/PDF/ schaerer.pdf $>$.

SCHREINER, Klaus. Einführung in die Museologie - ein Beitrag zu den theoretischen Grundlagen der Museumsarbeit. Neubrandenburg, 1982 [published as typoscript].

SCHREINER, Klaus. Forschungsgegenstand der Museologie und Disziplingenese. Neue Museumskunde, 1987, vol. 30, pp. 4-8.

SCHREINER, Klaus. Museologische Termini Auswahl. Neubrandenburg, 1982 [published as typoscript].

STRÁNSKÝ, Zbyněk Z. Cyberraum und Museumskultur. Museum aktuell, 2007, iss. 133, pp. 20-24.

STRÁNSKÝ, Zbyněk Z. Die Bildungs- und Erziehungsziele der Museumsausstellung als pädagogisch-museologisches Anliegen. Neue Museumskunde, 1982, vol. 25, pp. 45-51.

STRÁNSKÝ, Zbyněk Z. Die theoretischen Grundlagen der Museologie als Wissenschaft. In AUER, Hermann (ed). Museologie. Neue Wege - Neue Ziele. Bericht über ein internationales Symposium, veranstaltet von den ICOM-Nationalkomitees der Bundesrepublik Deutschland, Österreichs und der Schweiz 11.-14. Mai 1988 am Bodensee. München: K.G. Sauer, 1989, pp. 38-47. ISBN 978-3-598-10809-9.

STRÁNSKÝ, Zbyněk Z. Hat die Museologie einen Sinn? In SCHIMPFF, Volker and 
Wieland FÜHR (eds.). Historia in Museo. Festschrift für Frank-Dietrich Jacob zum 60. Geburtstag. Langenweißbach: Beier \& Beran, 2004, pp. 471-477. ISBN 978-3-930036-94-3.

STRÁNSKÝ, Zbyněk Z. Ist Museologie eine kommunistische Wissenschaft? Eine Entgegnung auf deutsche Einstellungen. Museum aktuell, 2001, iss. 68, pp. 27582761.

STRÁNSKÝ, Zbyněk Z. Metamuseologie. Museum aktuell, 2003, iss. 92, pp. 39743978; 2003, iss. 93, pp. 4028-4030; 2003, iss. 96, p. 4153.

STRÁNSKÝ, Zbyněk Z. Museologische Terminologie. Neue Museumskunde, 1988, vol. 31, pp. 12-17.

STRÁNSKÝ, Zbyněk Z. Museumsgegenstand - eine Welt sui generis. Metaphysik des Museumsgegenstandes. Neues Museum. Die österreichische Museumszeitschrift, 1993, iss. 3/4, pp. 48-56.

STRÁNSKÝ, Zbyněk Z. Noch eine „knapp gefaßte Museologie“. Museum aktuell, 2006, iss. 131, pp. 6-7.

VOGT, Arnold. Museologie und Museumspädagogik. Ihre Rahmenbedingungen und Perspektiven in Wissenschaft und Praxis. In FLÜGEL, Katharina and Arnold VOGT (eds.). Museologie als Wissenschaft und Beruf in der modernen Welt. Weimar: Verlag und Datenbank für Geisteswissenschaften, 1995, pp. 53-80. ISBN 978-3-929742-56-5.

WAIDACHER, Friedrich. Handbuch der Allgemeinen Museologie. 2nd, revised edition. Wien: Böhlau, 1996. ISBN 978-3-205-98445-0.

WAIDACHER, Friedrich. Museologie - knapp gefasst. Wien/Köln/Weimar: Böhlau, 2005. ISBN 978-3-205-77268-2.

WEBER, Lena. Klostermuseen im deutschsprachigen Raum. Bonn, University, 2013. Dissertation.

\section{MARKUS WALZ}

Hochschule für Technik, Wirtschaft und Kultur Leipzig, Fakultät Medien, Leipzig, Bundesrepublik Deutschland markus.walz@htwk-leipzig.de

Markus Walz is Professor of Theoretical and Historical museology at the University of Applied Sciences in Leipzig (HTWK). He studied European ethnology and doctoral studies in History. He did research traineeship at the Landesmuseum Koblenz, worked as Museum consultant for Eastern Westphalia and Lippe in the Westphalian Museum Office in Münster. Since 2001 he works at the University of Applied Sciences in Leipzig.

Markus Walz je profesorem teoretické a historické muzeologie na Vysoké škole pro technologii, hospodářství a kulturu v Lipsku (HTWK). Studoval evropskou etnologii a doktorská studia v oboru historie. Absolvoval vědeckou stáž v Zemském muzeu v Koblenzi, pracoval jako muzejní poradce pro Východní Vestfálsko a Lippe na Vestfálském úřadu pro muzea v Münsteru. Od roku 2001 působí na Vysoké škole pro technologii, hospodářství a kulturu v Lipsku. 